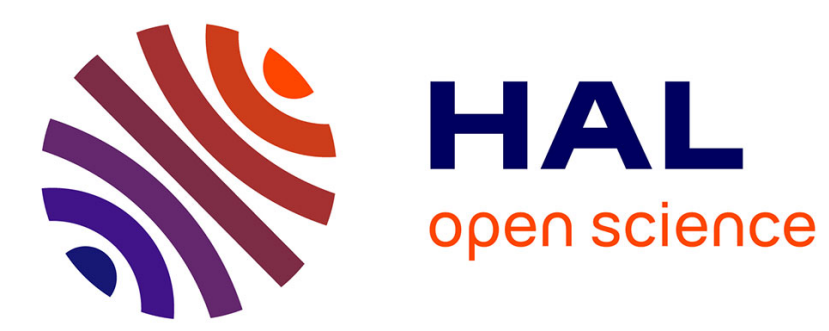

\title{
(Silence on) Adverbs in Plutarch Plat. Quaest. 10
}

Alessandro Garcea, Angelo Giavatto

\section{To cite this version:}

Alessandro Garcea, Angelo Giavatto. (Silence on) Adverbs in Plutarch Plat. Quaest. 10. Histoire Epistémologie Langage, 2005, 27 (2), pp.167-177. halshs-00095240

\section{HAL Id: halshs-00095240 https://shs.hal.science/halshs-00095240}

Submitted on 26 Jun 2015

HAL is a multi-disciplinary open access archive for the deposit and dissemination of scientific research documents, whether they are published or not. The documents may come from teaching and research institutions in France or abroad, or from public or private research centers.
L'archive ouverte pluridisciplinaire HAL, est destinée au dépôt et à la diffusion de documents scientifiques de niveau recherche, publiés ou non, émanant des établissements d'enseignement et de recherche français ou étrangers, des laboratoires publics ou privés. 


\title{
(SILENCE ON) ADVERBS IN PLUTARCH PLAT. QVAEST. 10*
}

\author{
Alessandro Garcea \& Angelo Giavatto \\ Université de Toulouse 2 - CNRS UMR 7597 \\ \& Università di Bologna, Italia
}

\begin{abstract}
RESUMÉ : Dans son dixième platônikon ABSTRACT : In order to justify the Platonic zêtêma, Plutarque essaie de justifier l'asser- formula that speech results from the blend of tion platonicienne selon laquelle le discours nouns and verbs, Plutarch tries to résulte de l'assemblage de noms et de ver- demonstrate that all other kinds of words are bes, les autres classes de mots n'étant pas not autonomous parts of speech (tenth des parties du discours autonomes. Curieuse- platônikon zêtêma). Strangely enough, he ment, Plutarque ne considère pas les adver- does not discuss adverbs, even while they bes, qui pourtant étaient reconnus par les were recognised by Alexandrinian grammagrammairiens alexandrins, comme Plutarque rians, as he himself seems to acknowledge lui-même semble le reconnaître au tout début when he mentions them at the very de sa discussion. A nos yeux, les adverbes beginning of his discussion. We will try to n'ont pas été oubliés inconsciemment. show that adverbs are not victims of an Plutarque a fondé toute sa démonstration sur involuntary omission. Plutarch based his une interprétation strictement grammaticale overall demonstration on a strictly grammade l'approche métaphysique de Platon. Aussi tical understanding of Plato's metaphysical est-il obligé de ne pas prendre en compte les viewpoint; he is therefore forced not to adverbes, car ils possèdent des caracté- discuss adverbs, since they possess peculiar ristiques morpho-sémantiques qui pourraient morpho-semantic features which could show montrer l'incohérence de son système. the inconsistency of his reconstruction.
\end{abstract}

MOTS-CLÉS : adverbe ; Plutarque ; Platon ; KEY WORDS : adverb, Plutarch; Plato; Stoïciens; grammaire grecque; Antiquité Stoics; Greek grammar; Greek antiquity; grecque; grammairiens grecs ;

Greek grammarians.

\section{INTRODUCTION}

With his tenth platônikon zêtêma (Mor. 1009B-1011E), ${ }^{1}$ Plutarch aims at justifying the Platonic formula that discourse results from the blend of nouns and verbs; as Plutarch says, ton logon ex onomatôn kai rhêmatôn kerannusthai (1009B). These words expressly refer to the Sophist, where Plato, adopting a metaphysical viewpoint, affirms:

In neither example [scil. neither 'walks', 'run', 'sleeps', nor 'lion', 'stag', 'horse'], indeed, do the words uttered supply information about any action or non-action, or any substance as of something which is or is not, until one mixes together the attributes with the names. Then it clicks and at once the most

\footnotetext{
* This paper is the product of joint authorship. The actual arrangement of $\S 1$ must be referred to Alessandro Garcea, that of $\S 0$ and 2-3 to Angelo Giavatto. We wish to thank Frédérique Ildefonse for having read a first draft of this paper.

${ }^{1}$ On this work see the commented text of Cherniss (1976, pp. 104-129), Göldi 1922, pp. 210, Wouters 1996 (especially on the relationship with Plato).
} 
elementary combination becomes an account (statement) of what might be called the most elementary and shortest kind. (262C, transl. de Rijk 1986) ${ }^{2}$

Justifying these assertions means for Plutarch to answer to the objection one could have raised to Plato for not having dealt with the other six parts of speech recognised by Alexandrinian grammarians. To this aim, Plutarch uses three sets of arguments: his own, which are mostly analogic, the Stoic ones ${ }^{3}$ and the Alexandrinian ones. In this study we will focus on a specific aspect of Plutarch's reasoning, i.e. the rôle of adverbs in the overall demonstration, that will lead us to the more general problem of classifying this part of speech in a 'Platonic' pattern.

The opening section of Plutarch's text states the discrepancy between the Platonic theory as he drafted it and the poetic ability of Homer, able to put all eight parts of speech in a single line: ${ }^{4}$

autos, iôn klisiênde, to son geras. ophr' eu eidêis (A 185) «Tentward going myself take the guerdon that well you may know it.» (transl. Cherniss 1976)

After the substitution of the particle - de with the correspondent preposition eis, this line effectively contains all parts of speech recognised by Alexandrinian grammarians; ${ }^{5}$ in particular, a paradigmatic example of an adverb, $e u$, that Plutarch clearly recognizes as such (epirrhêma, 1009C).

After such an (intentionally) sharp opposition, ${ }^{6}$ he starts to list his arguments to demonstrate the soundness of Plato's point of view.

\section{THE GENERAL CRITERIA FOR RECOGNITION OF PARTS OF SPEECH}

\section{Logic-syntactical criterion $(1009 C-D)$}

Plutarch asks whether noun and verb should be interpreted as the basic units of prôtos logos, the 'primary speech', which was also called protasis, later axiôma, and is the minimal condition to express a truth or falsehood, without needing anything else (oudenos allou prosdeêthentes). ${ }^{7}$ In this function, noun and verb are identical with subject (ptôsis) and predicate (katêgorêma), clearly interpreted by Plutarch in a strictly grammatical meaning.

\footnotetext{
${ }^{2}$ For other loci similes within the Platonic corpus see Cherniss 1976, p. 104 n. b ad 1009B and de Rijk 1984, pp. 231-234.

${ }^{3}$ According to Frede 1978/1987, p. 328 and Atherton 1993, p. 304 Stoics are the actual polemic goal of Plutarch; Wouters 1996 rather identifies it in the Alexandrinian grammarians.

${ }^{4}$ For the use of a single sentence containing all parts of speech in grammatical context see Apollonius Dyscolus synt. GG 2.2,17,1-15 and Priscianus inst. GL 116,5-25. On the Homeric example see also infra, § 2.d.

${ }^{5}$ See [Dionysius Thrax] 11 with Lallot $1998^{2}$, pp. 122-125 ad loc.

${ }^{6}$ Victim of a lacuna already pointed out by the scribes; we accept the satisfying text reconstruction of Cherniss.

${ }^{7}$ Plutarch is hinting at Plato's Sophist, where a connection as anthropos manthanei forms tôn logôn ho prôtos te kai smikrotatos (262c6-7: see also 262c10).
} 


\section{Semantic-referential criterion $\left(1009_{D}\right)$}

Following a phylogenetic approach, Plutarch adds that human beings likely needed an articulated language 'in the first place' (to prôton) in order to communicate each other and to designate actions (hai praxeis) and their agents (hoi prattontes autas), ${ }^{8}$ passions (ta pathê) and their patients (hoi paskhontes). We will hereafter refer to such expression of these four elements by means of $\Delta \pi^{4}$ ( $\Delta$ summing up diasaphein kai aposêmainein and dêloun).

\subsection{The semiotic inference $(1009 D-E)$}

Beside being respectively subject and predicate of a proposition, noun and verb are also signs with a definite lexical meaning. As no other kind of word has the same characteristics, it seems that they are the only semantic units (tauta sêmainein edoxe).

\subsection{The kinds of words irreducible to the semiotic dimension (1009D-E)}

Should one therefore consider the other kinds of words not significative like the groans or shouts of actors? A smile or the silence of an actor, Plutarch observes, makes the sentence more expressive (emphantikoteros), but none of them have nevertheless the force which is necessary to signify (anagkaian ekhei pros to sêmainein... dunamin: hereafter $\Sigma$ ), as noun and verb do; they rather possess an accessory one that embellishes the speech (epitheton tina poikillousa ton logon [sc. dunamin ekhein]).

- Up to this point, Plutarch's results can be summed up this way: if a given word designates actions, passions, agents or patients $\left(\Delta \pi^{4}\right)$, then it possesses semantic force $(\Sigma)$. This is the case of nouns and verbs. Plutarch does not exactly say what force is peculiar to other kinds of words.

\section{Properties of the other kinds of words}

\section{1. 'Extra-logos' properties (1009E-F)}

Plato's formula discussed by Plutarch says that the logos is a blend 'of' (ex) nouns and verbs and not that is formed 'by means of' (dia) them. Conjunctions (sundesmoi), prepositions (protheseis) and similar parts of speech (ta toiauta: we cannot be sure that this generic expression corresponds to or entails 'adverbs') make the arrangement of logos possible, but they do not blend any actual logos.

\subsection{Extra-semiotic properties (1010A)}

Taking 2.0-2.2 up, Plutarch shows that when we utter a verb ('beats' = action, 'is beaten' = passion) or a noun ('Socrates', 'Pythagoras', which could clearly be both agents and patients), we conceive something with our mind and we think about it (noêsai ti kai dianoêthênai). But words as 'indeed' (men), 'for' (gar), 'about' (peri) do not offer any notion of act or body (ennoia tis ... $\hat{e}$

\footnotetext{
${ }^{8}$ An almost literally quotation of Plato's Sophist (262a3-7).
} 
pragmatos $\hat{e}$ sômatos) ${ }^{9}$; therefore, they can only be used in association with nouns and verbs, but not autonomously, neither isolated nor combined. ${ }^{10}$

The one-to-one relationship between action/passion and parts of speech leads to a stronger inference: if a given word does not designate $\pi^{4}$, then it is not a part of speech.

Plutarch adds then two last criteria, which do not pertain to a logicphilosophical perspective:

\section{4. 'Emotive' criterion (1010B-C)}

Observing that Homer defines an epos ${ }^{11}$ 'offensive' or 'heart-breaking', Plutarch affirms that conjunctions, articles and prepositions cannot be qualified in the same way: only a verb, which expresses a (shameful) action or an (improper) passion, can.

\section{Stylistic criterion $(1010 \mathrm{C})$}

For the same reason (dio) the style of a writer can be evaluated on the basis of the nouns and verbs he employs: nobody, on the contrary, would judge his use of articles. ${ }^{12}$

- After having discussed the general criteria by means of which noun and verb are recognised as the only parts of speech, Plutarch focuses on the other kinds of words, using two sorts of arguments. A kind of word is not a part of speech if:

$\alpha$. it is external to $\log o s$, i.e. it has a subsidiary character [sections 6-7 and 10];

$\beta$. it can be brought back to onoma or rhêma, either on a morphological $\left(\beta^{1}\right)$ or semantic $\left(\beta^{2}\right)$ ground [sections 7-9 and 10].

\section{Articles (1010D-E)}

Answering the question whether they give any contribution to speech (sumballesthai pros logon), Plutarch compares them to salt in a dish of food and to water in a barley-cake. But while salt and water, even if 'external', are nevertheless necessary, this is not the case of articles, abolished in languages like Latin and absent in most of Homeric verses, without preventing clarity (saphêneia) or beauty (kallos) of expression.

\footnotetext{
${ }^{9}$ See Nuchelmans 1973, pp. 96-97.

10 For a similar remark on conjunctions which grammarians say sussêmainein consignificare see Garcea \& Lomanto 2003; Lallot 2003.

${ }^{11}$ Plutarch quotes the formular epos t' ephat' ek t'onomazen (see e.g. A 361), $\psi 183$ and $\theta$ 408-409.

12 According to Atherton 1993, p. 304, the account 1-5 follows the Peripatetic, possibly Theophrastean (see Simplicius cat. CAG 8,10,23-11,2, with Frede 1978/1987, pp. 328-329) distinction between parts of logos, which signify, and parts of lexis which do not. See also Ammonius (int. CAG 4.5,12,16-24; 40,21-30; 48,17-49,6; 59,26-60,3) on a general defence of this distinction, already made by Plato before Aristotle.
} 


\section{Connectives (1010E-1011C)}

They can only be considered an instrument for conjoining (organon ti sundetikon) and not a part of speech. Their subsidiary character can be compared to the strap in a load or to the glue which holds together the sheets of a book. ${ }^{13}$ Moreover, their connective property is not evident in all statements, but only in non-simple ones: according to the Stoic viewpoint, connectives build up molecular propositions from atomic ones, without operating on lower levels. Lastly, on an aesthetic ground, the speech is more emotional and more stirring in absence of conjunctions, i.e. in case of asyndeton. The argument that language is a disjointed enumeration, because its units cannot coexist but are at most successive (a sceptical claim, see Sextus Empiricus math. 8,81-84; 132; 136), ends this section.

\section{Pronouns $(1011 \mathrm{C})$}

They are a kind of noun (genos onomatos), both on morphologic (sharing of cases) and semantic (definite reference) grounds.

\section{Participles (1011C-D)}

They are a mixture of verb and noun (migma rhêmatos ... kai onomatos), both on morphologic (sharing of tenses and cases) and semantic (same value as nouns adjectives) grounds. ${ }^{14}$

\section{Prepositions (1011D-E)}

Plutarch makes use of both arguments $\alpha$ and $\beta$. Firstly, prepositions are not speech, but rather 'appurtenances' of it (peri tous logous ... ousai), as capitals, pedestals and bases. Secondly, they resemble bits and pieces of nouns (kommata kai thrausmata onomatôn): for 'incoming' (em-bênai), 'outgoing' (ek-bênai), 'foregoing' (pro-genesthai), and 'undersetting' (kath-hizein) are plainly contractions ${ }^{15}$ of 'coming within' (entos bênai), 'going without' (ektos bênai), 'going before' (proteron genesthai), 'setting underneath' (kato hizein), just as litho-bolein 'stoning' and toikh-ôrukhein 'housebreaking' are contractions of lithous ballein 'pelting with stones' and toikhous orussein 'breaking into houses'.

- The conclusion of Plutarch's reasoning at the end of the tenth Platonic Question is that all these kinds of words render some service (khreia) to speech, but they are not constitutive part of it. In the way of a Ringkomposition, Plutarch repeats that no more than verb and noun produce

\footnotetext{
${ }^{13}$ For these similes see now Garcea \& Lomanto 2003, pp. 41-44.

${ }^{14}$ See Priscian inst. GL 2,548,14-549,1 (= FDS 575), who confirms that Stoics called participle antanaklastos prosêgoria / appellatio reciproca.

${ }^{15}$ Atherton (1993: 304) thinks that prepositions can be considered "pieces of words" «since they also function as prefixes»; but Plutarch is here explicitly speaking of contraction. Atherton's interpretation could not moreover explain the comparison Plutarch draws between them and the fragments of letters and signs written by those in haste.
} 
the prôtê sunthesis admitting of truth and falsity; at this point he can also more strongly conclude that the other kinds of words are not parts of speech at all.

\section{ADVERBS}

What about adverbs? No mention of them among the examples of sections 1-5, nor - what is more surprising - in the discussion on single kinds of words in 610. H. Cherniss (1976, p. 128 n. b ad 1011E) observes that «of the six "parts of speech" besides noun and verb which had there been listed as present in Iliad i, 185 Plutarch has accounted for all except the adverb»; he thinks that this happened because the Stoics did not pay much attention to this morpho-lexical category. ${ }^{16}$ A. Wouters (1996, p. 323 n. 64) rather affirms: «due to inadvertence, I believe, he [Plutarch] omits the adverb»; he rightly rejects Cherniss' explanation affirming that «it is the Alexandrinian system which is under Plutarch's attack (sc. and not the Stoic one) [...] and thus we would expect him to argue his rejection of this meros as well».

We will try to find an alternative explanation for this strange silence on adverbs, discussing the following points:

a. the 'hidden' presence of adverbs in the analysis of prepositions (section 10);

b. the application to adverbs of $\alpha-\beta$ arguments used in 6-10;

c. the application to adverbs of the general criteria used in 1-5;

d. the relationship of adverbs with nouns.

a. Giving some examples for his claim that prepositions are pieces of nouns, Plutarch says that em-bênai «is evident contraction of» (sugkopê prophanês) entos bênai, ek-bênai of ektos bênai, pro-genesthai of proteron genesthai and kath-hizein of katô hizein; so for him these preverbs correspond to adverbs.

A similar taxonomic issue is discussed in Roman grammatical tradition. Varro
seems to have unified both prefixes/prepositions (at least the local $e x$, in, ad,
$a b$ ) and adverbs in a single class: see serm. Lat. frg. 267 p. $286-289 \mathrm{~F}$. = frg.
102 G. \& S., quoted by Scaurus orth. GL $7,29,8-11 .{ }^{17}$ On the other hand
Suetonius Tranquillus keeps these two classes distinguished claiming that
preverbs are always put before the verb, whereas adverbs occur after verbs or
adjective nouns (reb. uar. fr. 206 R., quoted by Julius Romanus in Charisius
p. $252,21-25$ B.)..$^{18}$

Referring to this identity, Plutarch calls the adverbs onomata. It can be translated in two ways:

\footnotetext{
${ }^{16}$ See $\Sigma^{\mathrm{m}}$ Heliod. GG 1.3,356,15-16 and $\Sigma^{\mathrm{l}}$ Heliod. GG 1.3,520,16-22 discussed infra, § 2.b.

${ }^{17}$ On the transmission of this Varronian doctrine in grammatical texts, see Wilmanns 1864 , pp. 112-115; Usener 1869/1913, pp. 201-215.

${ }^{18}$ See Schenkeveld 2004, pp. 130-131 ad loc.
} 
- as «words»; according to Cherniss (1976, p. 127 n. d ad loc.), «onomatôn here must have been meant in this general sense, since Plutarch proceeds to represent the prepositions in composition as fragments of adverbs and not of what he calls nouns» (our italics).

- specifically as «nouns»; as the recognised part of speech blended with verbs to make logos.

Cherniss' translation with the generic «words» would constitute a semantic hapax within the treatise, involving a term, onoma, which is, with rhêma, its actual focus. If we translate here onomatôn with «nouns», we avoid therefore an inconsistency that hardly could have escaped Plutarch's attention.

So the only time Plutarch mentions adverbs, he calls them nouns. The
hypothesis of such an identification should not seem astonishing, at least in
philosophical context. Starting from derivation like 'well' < 'good' and
'clearly' < 'clear', Ammonius hints at (and rejects) Alexander of Aphrodisias'
claim that adverbs are names (int. CAG 4.5,13,19-27); Alexander in his turn
could have made an inference from Aristotle top. 148a10-13, where
'beneficially' (ôphelimôs) and 'effectively' (poiêtikôs) are said to be
'inflexions' of 'beneficial' (ôphelimon) and 'effective' (poiêtikon) (see Blank
1996, p. 141 n. 75).

Our next steps will consist in showing whether such a connection between adverb and noun is possible and what kind of theoretic issue is hidden in a turn of phrase such as «pieces of nouns».

b. Could Plutarch have considered the adverbs as 'subsidiary to logos' $(\alpha)$ and (or) ready to be brought back to onoma or rhêma $(\beta)$ ? We shall note, for the moment, that in the case of the argument $\beta$, the Stoic viewpoint would easily have supported him:

They (sc. the Stoics) did not think that adverbs are admissible as a part of speech, but claimed that they grew beside nouns and verbs (paraphuesthai $\hat{e}$ tois onomasin $\hat{e}$ tois rhêmasin), those drawn from nouns (ta men apo onomatôn) beside nouns, those drawn from verbs ( $t a$ de apo rhêmatôn) beside verbs etc. ( $\Sigma^{1}$ Heliod. GG 1.3,520,16-18 = FDS 579)

c. At the end of $\S 1.3 .2$ we stated a quite strong result of Plutarch's set of arguments: every word that does not own the semantic characteristic of noun and verb, is not a part of speech. Does this criterion fit with adverbs? We can consider the particular case of an adverb mentioned by Plutarch in the account of prepositions, i.e. proteron:

i. genesthai and pro-genesthai plainly denote two actions different in meaning («to exist» on the one hand and «to pre-exist» on the other);

ii. since genesthai is the same as genesthai, the semantic difference between genesthai and pro-genesthai is determined, by subtraction, by the preverb pro-; 
iii. since pro- is contraction of the adverb proteron, this adverb is the element that establishes the semantic difference between genesthai and progenesthai. ${ }^{19}$

So the adverb does signify something, insofar as it changes the meaning of an expression that contains it. If it is capable of semantic power, Plutarch could have taken it back to verb and/or to noun status, as he did in the cases of pronoun, which assures identity of denotatum (at least in a definite proposition: ${ }^{20}$ Sokraten $=$ touton $)$, and of participle $($ ho sôphronôn $=$ ho sôphrôn).

A further analysis of proteron helps to understand why Plutarch renounced such an argument:

iv. proteron establishes a semantic difference in progenesthai not because it signifies an action/passion or an actor/patient $\left(\pi^{4}\right)$, but because it adds, with respect to genesthai, an element of meaning that concerns the time of action. $^{21}$

Even if endowed with semantic power, the adverb does not satisfy the condition of $\S 1.2 .2$, insofar as it signifies neither a praxis nor a prattôn, a pathos nor a paskhôn. To bring it back to onoma or rhêma on the semiotic ground would mean to admit the existence of words which do not express $\pi^{4}$ but are significative.

The analysis of the other adverbs present in the tenth quaestio Platonica - for instance entos bênai and ektos bênai with respect to bênai, but also $e u$ in the opening example - will lead to the same conclusion: adverbs give some semantic information, concerning spatial or qualitative aspects of an action, but they do not signify $\pi^{4}$.

d. At this point we can profitably go back to the argument $\boldsymbol{\beta}^{2}$ : the possibility of bringing back a kind of word to onoma and rhêma on a morphologic ground. Why does Plutarch not use this argument in the case of adverbs? We could think because adverbs share neither the cases of nouns (as pronouns and participles do) nor the tenses of verbs (as participles do). Going thoroughly into this first possible answer, we would find a more cogent reason.

The adverb $e u$ in Homer A 185, that is considered as such by Plutarch at the beginning of the treatise, is to bring back to eüs («good», «noble»). ${ }^{22}$

\footnotetext{
${ }^{19}$ This semantic influence of prefixes on the meaning of verbs was already been observed by Posidonius (frg. 45 E. \& K. = Apollonius Dyscolus con. GG 2.1,214,4-20). In his peri sundesmôn he claimed, against those who considered conjunctions meaningless, «that conjunctions differ from each other as epidounai differs form apodounai, as apaitein from prosaitein, and other such compound forms. He is confident that prepositions and conjunctions are a single part of speech».

${ }^{20}$ According to the Stoic definition: see Sextus Empiricus math. 8,96-97 (= SVF 2,205, LS 34H, FDS 915-916).

${ }^{21}$ See the etymologic definition of adverbs by Apollonius Dyscolus $a d u$. GG 2.1,119,5-6 and Sluiter 1990, pp. 74-105. For a comparison between Apollonius' and Dionysius' definition see Ildefonse 1997, pp. 367-372.

${ }^{22}$ See Chantraine $1990^{2}$, p. 388 s.u. eüs.
} 
This word is surely not a verb. But is it a noun? For the ancient grammatical system it is. More exactly, it is an onoma epitheton (see the definition of [Dionysius Thrax] 12). Plutarch could have therefore brought back adverbs to noun on a morphologic ground (and this could also explain why, discussing prepositions, he called nouns four adverbs). ${ }^{23}$ But such a connection with (this particular subclass of) nouns proves itself to be dangerous or even destructive for the argumentative system Plutarch puts together. A word like «good», classified as noun, and the adverb drawn from it, do not designate an agent or a patient - and they plainly do not signify an action or a passive state. So $\neg \Delta \pi^{4} a$. But on account of what we demonstrated in $\S 2$.c, we cannot say that they do not signify $(\neg \Sigma a)$ : we have to admit, again, that adverbs possess semantic force $(\Sigma a)$, which can be able to change the meaning of a statement.

Summing up, adverbs could and should with good reason have been discussed in the tenth quaestio Platonica: they perfectly fit with its theoretical issues, as their hidden - and, we would say, involuntary - presence in the discussion of preposition shows, not to mention the opening Homeric verse which contains one of them. They seem nevertheless to have been deliberately omitted by Plutarch, for the cogent reason that their semantic nature is a plain contradiction of his definition of onoma that informs all of the treatise.

An intriguing coincidence can function as further example of what we argued
above, in particular the inconsistency between Plutarch's account of parts of
speech and adjective as onoma epitheton.
If we look back on the opening Homeric example, we can see how
paradigmatic are its rhêma (eidêis) and its two onomata (klisiê and geras; to
them one should also add, to be more precise, the possessive adjective son). But
from $\Sigma^{\mathrm{d}}$ GG $1.3,58,13-19, \Sigma^{\mathrm{m}}$ Heliod. GG $1.3,357,29-36^{24}$ and Eustathius ad
Hom. X 59, 1256, 60-61 we know that grammarians used to quote another
Homeric as example of coexistence of all eight parts of speech, ${ }^{25} \mathrm{X} 59$ :
pros $d$ ' eme ton dustênon eti phroneont' eleêson « Furthermore, have
compassion of me, unhappy, while I still live ».
Could Plutarch have chosen this verse instead of A 185 ? According to our
reconstruction, he could not, insofar he would not have been ready:
• to give up klisiê and geras of A 185 ;
- to accept dustênos, the word of X 59 recognised as onoma by
grammarians, i.e. a modern adjective, because such a word does not
designate what we called $\pi^{4}$.
If the onoma, as Plutarch conceived it, refers exclusively to a pragma or to a

23 See also Ammonius' account discussed supra, § 2.a. Ammonius further rejects identification of adverbs with nouns claiming that even if morphologically connected to nouns, on the syntactical level adverbs cannot be neither a subject nor a predicate in propositions (int. CAG 4.5,13,27-14,2).

${ }^{24}$ Where the verse is quoted in order to show that nouns and verbs are more important than other expressions and essential to create logos (11. 27-28).

${ }^{25}$ A search in Thesaurus Linguae Graecae does not give any result for A 185 in the section Grammatica. 
pathos, and therefore to a substance, dustênos rather refers to a quality; in X 59 such a property is peculiar to a substance defined by the personal pronoun eme - a point that perfectly confirms the semantic argument of $\mathbf{8}$ for interpreting the pronoun as genos onomatos. So, if - according to Plutarch - a noun exclusively designates a substance, a term like dustênos that does not fit this condition cannot be a noun; X 59 would therefore lack of a noun and could not be paradigmatic in using all eight parts of speech.

\section{CONCLUSIONS}

Why does Plutarch accept such a narrow conception of noun that forces him to avoid discussion of adverbs?

Talking about the need of language among human beings, Plutarch himself specified that they expressed to prôton ('in the first place', 'at first') ${ }^{26}$ actions, agents, passions and patients. A word like proteron (see supra, § 2.c) shows that such primary and basic need is nevertheless not the only one within the limits of language: it does not prevent from signifying other aspects of reality, for instance time, way or place of an action - as adverbs do. In the rest of his discussion Plutarch seems to 'neglect' this particular issue and uses the Platonic definition of prôtos logos as definition of language tout court. So the absence of adverbs from his taxonomy can be interpreted as the most evident sign of this radicalization: the Platonic model of the Sophist, according to which knowledge comes not from denomination of isolated substances but from the expression of their mutual link, ${ }^{27}$ becomes a grammatical pattern in form of subject + predicate, used by Plutarch as the sole criterion to define a part of speech. ${ }^{28}$

adresse des auteurs : <agarc@libero.it> <angelogiavatto@hotmail.com>

\footnotetext{
${ }^{26}$ An expression surely original although it hardly fits with the syntax of this sentence, as textual tradition shows (see Cherniss 1976: 106 app.).

${ }^{27}$ See Soph. 261E-262A: «The vocal signs we use to signify a substance and its attribute are surely of two sorts; one called 'names', the other 'attributes'. By 'attribute' we mean an expression significative of actions or states; by 'name' the vocal sign used for the things themselves subject to those actions or states»; 262A: «Well, an account (statement) never consists solely of names uttered in succession nor yet of attributes uttered apart from names» (transl. de Rijk 1986).

${ }^{28}$ A grammarian called Romanus and his pupil Philoponus avoid the kind of fallacy to which Plutarch falls in substituting for the mention of substance (ousia) in the traditional definition of noun that of quality (poiotês), because quality can entail substance but not vice versa (Choeroboscus GG 4.1,106,3-10). Common quality can entail not only general substance (e.g. hippos "horse") but also its characteristics (e.g. leukos "white"). Such a definition recognizes an aspect of reality that is related to substance as modality is related to action. This kind of theoretical pattern could have been the way of allowing grammatical existence to adverbs (see Barnes 1991, on the case of Ammonius).
} 


\section{REFERENCES}

Atherton, C. (1993). The Stoics on Ambiguity, Cambridge, University Press.

Barnes, J. (1991). « Ammonius and Adverbs », in H. Blumenthal \& H. Robinson (eds.), Aristotle and the Later Tradition, Oxford Studies in Ancient Philosophy Supplementary volume, 145-163.

Blank, D. (1996). Ammonius. On Aristotle On Interpretation 1-8, London, Duckworth.

Cherniss, H. (1976). Plutarch's Moralia in Seventeen Volumes, XIII part I, 999C-1032F, Cambridge MA - London, Loeb.

Chantraine, P. $\left(1990^{2}\right)$. Dictionnaire étymologique de la langue grecque. Histoire de mots, Paris, Klincksieck.

de Rijk, L.M. (1986). Plato's Sophist. A Philosophical Commentary, Amsterdam Oxford - New York, North-Holland Publishing Company.

Frede, M. (1978/1987). « Principles of Stoic Grammar », in J.M. Rist (ed.), The Stoics, Berkeley - Los Angeles, University of California Press, 27-75 = Essays in Ancient Philosophy, Minneapolis, University of Minnesota Press, 301-337.

Garcea, A. \& Lomanto, V. (2003). «Varron et Priscien: autour des verbes adsignificare et consignificare », Histoire Épistémologie Language 25/2, 33-54.

Göldi, O. (1922). Plutarchs sprachliche Interessen, Diss. Zürich.

Ildefonse, F. (1997). La naissance de la grammaire dans l'antiquité grecque, Paris, Vrin.

Lallot, J. (1998²). La grammaire de Denys le Thrace, Paris, CNRS Éditions.

Lallot, J. (2003). «A propos des syncatégorèmes: consignification et signification adjacente dans la tradition logico-grammaticale grecque », Histoire Épistémologie Language 25/2, 9-32.

Schenkeveld, D.M. (2004). A Rhetorical Grammar. C. Iulius Romanus, Introduction to the Liber de Aduerbio as Incorporated in Charisius' Ars Grammatica II.13, Leiden, Brill.

Sluiter, I. (1990). Ancient Grammar in Context. Contributions to the Study of Ancient Linguistic Thought, Amsterdam, VU University Press.

Usener, H. (1869/1913). «Varronische Exzerpte », Rheinisches Museum 24, 94-114 = Kleine Schriften 2, Leipzig \& Berlin, Teubner, 201-223.

Wilmanns, A. (1864). De M. Terenti Varronis libris grammaticis, Berlin, Weidmann.

Wouters, A. (1996). «Plutarch's Comments on Plato's 'Grammatical' (?) Theories. A Few Remarks on Quaestio Platonica X », in L. van der Stockt (eds.), Plutarchea Lovaniensia. A Miscellany of Essays on Plutarch, Studia Hellenistica 32, Louvain, Peeters, 309-328. 